\title{
PEMETAAN PENELITIAN ORIENTALIS TERHADAP HADIS MENURUT HARALD MOTZI
}

\author{
Ulummudin \\ UIN Sunan Kalijaga Yogyakarta. Jl. Laksda Adisucipto, Papringan, Caturtunggal, Depok, Sleman, \\ 55281, Daerah Istimewa Yogyakarta, Indonesia \\ Email: Ulummudin53@gmail.com
}

DOI: http:dx.doi.org/10.32505/al-bukhari.v3i1.1468

Submitted: 2020-03-07 | Revised: 2020-04-28 | Accepted: 2020-04-29

\begin{abstract}
This paper focuses on maping hadiths studies which has been done by orientalists according to Harald Motzki. So far, the maping is always seen based on an assuption which results three sections namely sceptic, non-sceptic, and middle ground. Unlike prior studies, Motzki tries to divide hadiths studies in the West based on the method they use Based on it, it is obtained a conclusion that hadiths studies in the West are not stagnant and similiar. On the contrary, it undergoes a progress time by the time. Based on the method employed to examine the authenticity of hadiths. The study of hadith in the West can be classified into four divisions. First, is matan which was introduced by Ignaz Goldziher, Josep Schacht, and Marston Speight. Second, is dating based on collections of hadis books with Josep Schacht as a initiator. Third, is dating by isnad which was started by Josep Schacht and Juynboll. Fourth, is isnad-cum-matan which was embarked by Harald Motzki.
\end{abstract}

Keywords: Hadith, Orientalist, Maping, Harald Motzki.

\begin{abstract}
Abstrak
Tulisan ini mengkaji tentang pemetaan kajian hadis yang dilakukan oleh para orientalis menurut Harald Motzki. Selama ini, pemetaan yang berkembang selalu dipandang berdasarkan asumsi yang dapat dibagi menjadi tiga yaitu skeptis, non-skeptis, dan middle ground. Kemudian, Motzki berusaha untuk memetakan kajian hadis orientalis dari sudut pandang berbasiskan metode. Dari pemetaan tersebut diperoleh suatu kesimpulan bahwa studi hadis di Barat tidak stagnan dan seragam, sebaliknya, berkembang dari waktu ke waktu. Berdasarkan metode yang digunakan untuk menguji keotentikan hadis, kajian hadis oleh para orientalis dapat dibedakan menjadi empat bagian. Pertama, metode yang menggunakan matan. Tokohnya adalah Ignaz Goldziher, Josep Schacht, dan Marston Speight. Kedua, penanggalan berdasarkan koleksi kitab hadis dengan tokohnya Josep Schacht. Ketiga, penanggalan berdasarkan isnad. Metode ini masih diwakili oleh Schacht dan Juynboll. Keempat, metode yang menggunakan isnad-cum-matan yang diajukan oleh Harald Motzki sendiri.
\end{abstract}

Kata Kunci: Hadis, Orientalis, Pemetaan, Harald Motzki 


\section{Pendahuluan}

Ketika berbicara terkait studi hadis di Barat, para pengkaji (orientalis) dapat diklasifikasikan menjadi tiga golongan berdasarkan asumsi yang digunakan yaitu skeptis, non-skeptis, dan middle ground. ${ }^{1} \mathrm{Hal}$ itu sudah menjadi pembagian umum untuk memetakan kajian hadis di Barat. Padahal, ini bukan satu-satunya pemetaan yang ada. Pemetaan lain yang digunakan untuk membaca sejarah tersebut sangat dimungkinkan. Salah satunya adalah pembagian yang dilakukan oleh Harald Motzki dalam tulisannya yang berjudul "Dating Muslim Tradistions: A Survey”.

Sejarah kajian hadis di Barat ini tidak diketahui pasti siapa yang memulainya karena ada perbedaan pendapat di kalangan para ahli. ${ }^{2}$ Namun, jika dibandingkan dengan sarjana Muslim, ada perbedaan cara pandang yang signifikan antara keduanya. Sarjana Muslim memandang hadis sebagai sumber hukum, moral, inspirasi keagamaan, tafsir al-Qur'an dan sejarah awal mula Islam.

\footnotetext{
${ }^{1}$ Mar'ah Nailul Faroh, Hadis dan Orientalis (Teori Ignaz Gholdziher dan Joseph Schacht), 9.

${ }^{2}$ Idri, Perspektif Orientalis tentang Hadis Nabi: Telaah Kritis dan Implikasinya terhadap Eksistensi dan Kehujjahannya, dalam Al-Tahrir, Vol. 11, No. 1, (2011), 201.
}

Sementara, sarjana Barat lebih terfokus pada pendekatan sejarah sebagai titik tolaknya. $^{3}$

$$
\text { Perjalanan sejarah panjang }
$$
dalam studi hadis di Barat tersebut, berusaha dipetakan oleh Motzki. Ia melihat adanya dinamika dalam studi hadis yang dilakukan oleh sarjanasarjana Barat. Oleh karena itu, tulisan ini akan mengungkap pembagian metode yang dilakukan oleh Motzki terhadap sarjana Barat berdasarkan penanggalan suatu hadis. Ia tidak hanya memaparkan metode mereka, tetapi juga mengkritisinya.

\section{Sejarah Awal Kajian Hadis di Barat}

Sebagaimana telah disebutkan di atas bahwa kajian hadis di Barat tidak diketahui secara pasti siapa yang memulainya. Namun, banyak yang beranggapan bahwa Ignaz Gholdziher adalah orientalis pertama yang menjadikan hadis sebagai objek kajiannya, termasuk menurut MM. Azami. Akan tetapi, hal ini dibantah oleh A.J. Wensick dalam The Importance of Tradition for Studies of Islam yang menunjuk Snouck Hurgronje sebagai orang pertama yang mengkaji hadis. Jauh sebelum

\footnotetext{
${ }^{3}$ Harald Motzki, Dating Muslim Tradistions: A Survey, dalam Arabica (Leiden: Koninklijke Brill, 205), Vol. 52, 204.
} 
Gholdziher, ia sudah mengkaji hadis tentang zakat dan Imam Mahdi. ${ }^{4}$

Sementara, pendapat lain mengatakan bahwa Gustav Weil (18081889) adalah orang pertama yang mengkaji hadis, lalu disusul berturutturut oleh Alois Sprenger (1813-1893), William Muir (1819-1905), dan Reinhart Dozy (1820-1883). Mereka semua mempunyai sikap yang sama dalam memandang hadis yaitu skeptis. Artinya, mereka meragukan keotentikan sebagian hadis. Bahkan, Weil sampai pada kesimpulan bahwa semua hadis yang terdapat dalam Sahih Bukhari tidak dapat diterima. Berbeda dengan Weil, Sprenger, Muir dan Reinhart meyakini hadis yang telah terkodifikasikan sebagiannya otentik. ${ }^{5}$

Tokoh-tokoh tersebut masih mencampurkan kajian hadis dengan sejarah Nabi Muhammad dan Islam. Kemudian, baru di tangan Goldziher, hadis menjadi sebuah disiplin ilmu yang dikaji secara sistematis. ${ }^{6}$ Ia berhasil membuat sebuah karya yang

\footnotetext{
${ }^{4}$ Wahyudin Darmalaksana, Hadis di Mata Orientalis: Telaah atas Pandangan Ignaz Goldziher dan Joseph Schacht, (Bandung: Benang Merah, 2004), 75-76.

5 Muh. Zuhri, Perkembangan Kajian Hadis Kesarjanaan Barat, dalam Ulul Albab Vol. 16, No. 2, (2015),. 217.

${ }^{6}$ Ali Masrur, Skeptisisme Ignaz Goldziher (1850-1921) terhadap Autentisitas Hadits dan Berbagai Tanggapannya, dalam jurnal Wawasan, Vol. 34, No. 2, (2011), 114.
}

menjadi rujukan orientalis-orientalis sesudahnya. ${ }^{7}$ Oleh karena itu, Goldziher dianggap sebagai "Bapak Orientalis" dalam bidang hadis.

\section{Pemetaan Ditinjau dari Segi Metode}

Terkait kemunculan asumsiasumsi seperti skeptis, non-skeptis, dan middle ground dalam penelitian hadis erat kaitannya dengan metode penanggalan hadis yang digunakan. Metode penanggalan adalah suatu hal lumrah yang dipakai oleh para sejarawan dalam menganalisis objeknya, tak terkecuali dalam bidang hadis. ${ }^{8}$ Hal ini sesuai dengan titik tolak yang digunakan para orientalis dalam studi hadis yaitu pendekatan sejarah.

Selanjutnya, Harald Motzki membagi kajian hadis di Barat menjadi empat metode. Pertama, metode yang menggunakan matan. Kedua, penanggalan berdasarkan koleksi kitab hadis. Ketiga, penanggalan berdasarkan isnad. Keempat, metode yang menggunakan matan dan isnad. ${ }^{9}$ Motzki

7 Muh. Zuhri, Perkembangan Kajian Hadis Kesarjanaan Barat, 217.

${ }^{8}$ Sahiron Syamsuddin, Pemetaan Penelitian Orientalis Terhadap Hadis, dalam Orientalisme al-Qur'an dan Hadis, ed. Nur Kholis setiawan \& Sahiron Syamsuddin, (Yogyakarta: Nawesea Press, 2007), 50.

${ }^{9}$ Harald Motzki, Dating Muslim Tradistions: A Survey, dalam Arabica, 205. 
tidak hanya memaparkan metode mereka, tetapi juga mengkritisinya.

\section{Penanggalan Hadis berdasarkan matan}

Studi hadis di Barat diawali dengan analisisnya terhadap matan. Dalam tradisi Islam, kajian seperti ini dikenal dengan istilah kritik matan. Menurut al-Tibbi yang dikutip oleh Hashim 'Abbas, yang dimaksud dengan matan hadis adalah kata-kata yang membentuk makna dalam sebuah hadis. Sehingga, setiap matan hadis mengandung lafal teks dan makna atau konsep. Letak matan dalam hadis selalu berada setelah rangkaian sanad. ${ }^{10}$ Intinya, matan adalah apa yang disabdakan rasul kepada para sahabatnya.

Sementara, yang dimaksud dengan kritik matan ialah suatu cara menganalisis teks atau redaksi hadis untuk menguji keabsahan hadis, sehingga dapat dibedakan mana yang sahih dan tidak. Dengan kritik matan, suatu hadis dikatakan sahih jika terbebas dari syad dan 'illat. ${ }^{11}$ Untuk mendapatkan kesimpulan tersebut, ada langkah-langkah yang harus ditempuh.

${ }^{10}$ Hasjim Abbas, Kritik Matan Hadis, (Yogyakarta: Teras, 2004), 13-14.

${ }^{11}$ Umi Sumbullah, Kritik Hadis: Pendekatan Historis dan Metodologis, (Malang: UIN Malang Press, 2008), 94.
Pertama, kritiks teks dengan melakukan analisis kebahasaan. Kedua, analisis terhadap makna teks itu sendiri apakah layak diamalkan dan dijadikan hujjah atau tidak. Ketiga, penelusuran ulang terhadap kandungan makna apakah dipraktekkan oleh Nabi atau sahabat. $^{12}$

Menurut Motzki, kritik ini yang digunakan oleh para orientalis awal dalam melakukan pengkajian terhadap hadis. Mereka menjadikan teks atau redaksi hadis sebagai sasaran analisisnya. Dalam pandangan Motzki, setidaknya ada tiga tokoh yang menempuh cara seperti ini. Mereka adalah Ignaz Goldziher, Joseph Schacht, dan Marston Speight.

\section{Ignaz Goldziher}

Berbicara mengenai orientalis dalam studi hadis, tentu tidak akan lepas dari sosok Ignaz Gholdziher. Nama lengkapnya adalah Ignac (Yitzhaq Yehuda) Goldziher, lahir di kota Szekesfehervar pada 22 Juni 1850 dan meninggal pada tanggal 13 November 1921. Ia adalah seorang keturunan Yahudi berkebangsaan Hungaria. Pendidikannya ditempuh di berbagai tempat seperti Budapest, Berlin, Leipzig, dan Leiden. Bahkan, Hadis, 16.
${ }^{12}$ Hasjim Abbas, Kritik Matan 
untuk memahami Islam, ia belajar langsung di Syria, Palestina, dan Mesir yang saat itu masih dalam cengkraman kolonialisme. $^{13}$

Terkait dengan hadis, Goldziher menulis buku dalam bahasa Jerman dengan judul Mohammedanische Studien (1890) dan kemudian diterjemahkan menjadi Muslim Studies (1971) dalam bahasa Inggris. Buku ini dianggaap sebagai pedoman utama bagi orientalis ketika mengkaji hadis. Dalam bukunya tersebut, ia menawarkan sebuah metode kritik matan hadis sebagai satu-satunya cara untuk mengukur keotentikan hadis.

Dalam hal ini, ia tidak mempertimbangkan kritik sanad seperti yang berlaku dalam dunia Islam. ${ }^{14}$

Sebelum lebih jauh membahas tentang kritik matan, di sini perlu dijelaskan terlebih dahulu konsep hadis dan sunnah menurut Goldziher secara ringkas. Ia memaknai sunnah sebagai sebuah kebiasaan atau adat istiadat yang disakralkan. Dengan kata lain, sunnah merupakan praktek-praktek yang dilakukan oleh para sahabat yang

${ }^{13}$ Ali Masrur, Skeptisisme Ignaz Goldziher (1850-1921) terhadap Autentisitas Hadits dan Berbagai Tanggapannya, 115.

${ }^{14}$ Wahyudin Darmalaksana, Hadis di Mata Orientalis: Telaah atas Pandangan Ignaz Goldziher dan Joseph Schacht, 87100. mencontoh apa yang dilakukan Nabi dalam ibadah dan hukum. Sementara, hadis adalah bentuk pernyataan dari sunnah atau praktek-praktek tersebut. ${ }^{15}$ Perbuatan Nabi yang dipraktekkan para sahabat, akan diteruskan oleh generasi tabi'in dan begitu seterusnya. Mereka membutuhkan pernyataan khusus yang dapat meyakinkan mereka bahwa hal itu bersumber dari Nabi.

Oleh sebab itu, menurut Goldziher seperti yang diungkapkan oleh Motzki, pemahaman tersebut membawa pada satu implikasi yang menyatakan bahwa hadis secara umum berasal dari awal abad kedua. Ia menganggap sebagian besar hadis-hadis yang telah terbukukan adalah hasil dari perkembangan Islam awal dalam bidang agama, sejarah, dan sosial. Ia meragukan bahwasanya hadis mempunyai akar sampai nabi. Baginya, hadis hanyalah bentuk respons dari masyarakat Islam yang sedang berkembang, sehingga setiap hal harus mempunyai sandarannya kepada nabi. Karena itu, hadis mulai diproduksi untuk menjawab kompleksitas kehidupan terutama pada masa

\footnotetext{
${ }^{15}$ Ignaz Goldziher, Introduction to Islamic Theology and Law, terj. Andras dan Ruth Hamori (Princeton: Princeton University Press, 1981), 37.
} 
kekuasaan Umayyah dan abad pertama dinasti Abbasiyah. ${ }^{16}$

Di sini jelas bahwa Goldziher menyangsikan keotentikan hadis yang selama ini menjadi keyakinan bagi seorang Muslim. Lebih lanjut, ia mengkritik ulama Islam yang tidak mempertimbangkan matan sebagai kriteria kesahihan hadis. Matan yang bertentangan dengan sejarah dan akal sehat akan tetap diterima selama sanadnya tidak bermasalah. ${ }^{17}$ Padahal, pada masa sahabat kritik matan pernah dilakukan. Tokohnya adalah Abu Bakar yang sangat hati-hati ketika menerima informasi yang disandarkan pada Nabi. Ia akan menguji kebenaran hadis terlebih dahulu sebelum mempercayainya. ${ }^{18}$

Kemudian, Motzki memberikan implikasi terhadap pernyataan Goldziher. Jika yang dimaksud adalah sebagian besar hadis, berarti sebagian kecil hadis mungkin saja berasal dari periode yang lebih tua yakni pada awal pertengahan abad pertama Hijriyah, bukan pada awal abad kedua. Baginya, jika prinsip Goldziher terkait hadis ini benar, maka sebetulnya bukan

\footnotetext{
${ }^{16}$ Harald Motzki, Dating Muslim Tradistions: A Survey, dalam Arabica, 207.

17 Muh. Zuhri, Perkembangan Kajian Hadis Kesarjanaan Barat, 219.

${ }^{18}$ Hasjim Abbas, Kritik Matan Hadis, 27-28.
}

permasalahan otentisitas suatu hadis, melainkan keterlambatan sebuah tradisi atau sunnah. ${ }^{19}$

$$
\text { Lebih jauh Goldziher }
$$
mengungkapkan, setidaknya ada empat faktor yang menjadi indikasi atau alasan suatu hadis dipalsukan. Keempat faktor tersebut adalah sebagai berikut: ${ }^{20}$

Pertama, perselisihan agama dan politik pada saat komunitas Islam lahir. Tentu yang dimaksud komunitas Islam di sini adalah masa Umayyah. Goldziher membuat sebuah analogi, semakin sekuler rezim Umayyah, semakin kuat orang-orang Muslim yang saleh berpegang teguh kepada ajaran nabi dan khalifah empat. Namun, rezim juga tidak berdiam diri untuk menjustifikasi semua tindakannya. Mereka memerintahkan ulama yang oportunis untuk menciptakan hadis palsu yang disandarkan sampai nabi. Hal semacam ini banyak terjadi terutama pada pertengahan kedua abad pertama $\mathrm{H}$.

Kedua, pemalsuan hadis terjadi pada saat Abbasiyah mengambil alih kekhalifahan dari dinasti Umayyah pada abad kedua H. Kebijakan penguasa baru terkait keagamaan yang

\footnotetext{
${ }^{19}$ Harald Motzki, Dating Muslim Tradistions: A Survey, dalam Arabica, 207.

${ }^{20}$ Harald Motzki, Dating Muslim Tradistions: A Survey, dalam Arabica, 207208.
} 
terfokus pada fikih mendorong pada penciptaan hadis. Ulama yang tunduk pada rezim akan memberikan fatwa yang sesuai dengan keinginan penguasa, walaupun dengan cara memalsukan hadis.

Ketiga, pertentangan antara ahl al-ra'y dan ahl al-hadis. Pertentangan ini terjadi pada pertengahan kedua abad kedua Hijriyyah. Pada era ini banyak hal terkait dengan suatu hukum diperlukan. Jika mereka tidak menemukan kasus yang sama dengan masa nabi, mereka tidak segan untuk menciptakannya.

Keempat, ketidakpuasan dari kelompok yang berseberangan dengan keluarga kerajaan dalam masalah agama dan politik. Mereka akan mencari cara untuk memberontak, dan untuk meyakinkan para pendukungnya, mereka terkadang menciptakan hadis palsu. Begitu pula sebaliknya, pihak kerajaan akan mencari dalil untuk menjustifikasi tindakannya dalam rangka melawan para pemberontak. Persaingan bukan hanya pada kedua kelompok tersebut, tetapi juga sukusuku, klan-klan, kota-kota, dan ulamaulama.

Salah satu contoh pemalsuan hadis yang dilakukan atas perintah penguasa adalah hadis tentang balapan merpati. Khalifa al-Mahdi (775 M-785
M) sangat senang terhadap atraksi perlombaan merpati. Akan tetapi, hal tersebut dianggap sebagai suatu perbuatan yang tidak pantas oleh para ulama. Untuk melegitimasi hal tersebut, ia memerintahkan seorang ulama untuk menambahkan satu kata dalam sebuah hadis agar balapan merpati dibolehkan. ${ }^{21}$

Motzki mengakui bahwa Goldziher berhasil menghadirkan contoh-contoh sunnah dan hadis yang menggambarkan perkembangan agama, politik, dan hukum. Namun, ia mempertanyakan apakah adil hanya dengan sedikit contoh lantas menarik kesimpulan bahwa kebanyakan hadis adalah palsu. Contoh-contoh itu hanya berlaku pada hadis-hadis tertentu. ${ }^{22}$ Adapun hadis yang lain belum tentu hadisnya palsu sebelum dilakukan penelitian, mengingat hadis yang jumlahnya ribuan.

\section{Marston Speight}

Marston Speight mencoba untuk merekonstruksi perkembangan kronologi suatu hadis dengan membandingkan variasi-variasi matannya. Ia memulai dengan asumsi bahwa sebelum terkompilasi dalam

\footnotetext{
${ }^{21}$ Harald Motzki, Dating Muslim Tradistions: A Survey, dalam Arabica, 209.

${ }^{22}$ Harald Motzki, Dating Muslim Tradistions: A Survey, dalam Arabica, 209.
} 
bentuk buku, hadis merupakan tradisi oral atau lisan. Metodenya terdiri dari beberapa langkah berikut ini: ${ }^{23}$

Pertama, mengumpulkan bahan dari sembilan belas hadis yang dianggap variasinya terkait dengan isi matan;

Kedua, mengatur matan sesuai dengan kompleksitasnya;

Ketiga, menganalisis setiap teks yang meliputi perkembangan, keterpaduan elemen-elemennya, gaya bahasa, dan kosa kata karena ini akan mengungkap perkembangan matan dari yang awal sampai akhir;

Keempat,mengklasifikasikan teks-teks berdasarkan isi yang terkait.

Premis-premis yang dibangun Speight ketika menganalisis teks adalah sebagai berikut: ${ }^{24}$

Pertama, teks-teks (matan) yang singkat lebih tua daripada yang menjelaskannya secara detail;

Kedua, ucapan laporan lebih awal daripada ucapan langsung

\section{Josep Schacht}

Orientalis kedua yang digolongkan oleh Motzki sebagai orang yang melakukan penanggalan berbasis

\footnotetext{
${ }^{23}$ Harald Motzki, Dating Muslim
} Tradistions: A Survey, dalam Arabica, 212.

${ }^{24}$ Harald Motzki, Dating Muslim Tradistions: A Survey, dalam Arabica, 212213. matan adalah Josep Schacht. Ia berasal dari Polandia yang lahir pada tanggal 15 Maret 1902 di Ratibor dan meninggal 1 Agustus 1969 di New Jersey Amerika. Ia mengenyam pendidikan di Universitas Berslauw sampai meraih gelar doktor dan Universitas Leipzig. Ia bergelut dengan bidang kajian filologi, teologi, dan bahasa-bahasa Timur. Selain di dua universitas tersebut, ia juga pernah belajar di Oxford dan kemudian mengajar di Leiden sebelum pindah ke Universitas Columbia, New York Amerika. ${ }^{25}$

Karyanya yang terkenal dalam bidang hukum Islam adalah The Origin of Muhammadan Jurisprudence (Oxford, 1950). Perkenalannya dengan hadis diawali dari kajiannya terhadap hukum Islam. Secara otomatis, ia akan bersinggungan dengan sumber hukum Islam itu sendiri yakni al-Qur'an dan hadis. Berbeda dengan al-Qur'an, ia mempersoalkan keotentikan hadis. Dalam kajiannya tentang hukum, ia berkesimpulan bahwa hadis-hadis tentang hukum tidak mempunyai keterkaitan dengan Nabi. Kalau pun

\footnotetext{
${ }^{25}$ Wahyudin Darmalaksana, Hadis di Mata Orientalis: Telaah atas Pandangan Ignaz Goldziher dan Joseph Schacht, 109110.
} 
ada, itu hanya dijadikan sebagai pendukung. $^{26}$

Kitab hukum yang menjadi acuannya adalah al-Umm karya Imam Syafi'i. Kitab ini dianggap sebagai koleksi tertua yang memuat hadis-hadis terkait dengan hukum Islam. Dengan demikian, ia berkesimpulan bahwa hukum Islam lahir pada abad kedua Hijriyah dimana kitab ini lahir. Begitu pula dengan hadis-hadis yang terkaandung di dalamnya, secara tidak langsung disinyalir sebagai produk baru yang terlepas dengan kehidupan Nabi di masa lalu.

Berbeda dengan Goldziher, Josep Schacht tidak hanya mendasarkan pada matan hadis, tetapi juga pada hasil dari kombinasi pendekatan-pendekatan yang berbeda. Ada empat tahapan pendekatan yang dilakukan dalam menentukan keotentikan suatu hadis. Pertama, rekontruksi hipotesis terhadap perkembangan teori hukum Islam yang didasarkan pada studi terhadap risalatrisalat teori hukum Imam al-Syafi'i. Kedua, metode penanggalan sunnah yang didasarkan pada koleksi-koleksi yang pertama kali muncul. Dalam konteks Schahct, al-Umm adalah kitab pertama dalam hadis-hadis hukum. Ketiga, membandingkan matan-matan

26 Muh. Zuhri, Perkembangan Kajian Hadis Kesarjanaan Barat, 220. hadis. Keempat, membandingkan sanad-sanadnya. ${ }^{27}$

Premis-premis yang digunakan Schacht terkait penanggalan matan adalah:

Pertama, sebuah hadis harus diberi tanggal dengan menempatkan kandungannya ke dalam perkembangan hukum;

Kedua, Hadis yang mempunyai qawaid fiqih pendek lebih awal daripada yang berbentuk narasinarasinya;

Ketiga, kaidah-kaidah yang tidak bernama lebih awal dibanding otoritas tertentu;

Keempat, Pernyataan yang singkat pada matan dipandang lebih awal daripada pernyataan yang disebutkan secara detail.

Kelima, Matan yang berisi masalah yang dijelaskan secara implisit lebih tua dibanding matan yang dijelaskan secara eksplisit.

\section{Penanggalan Berdasarkan Kitab-} Kitab Hadis

Josep Schacht tidak hanya menjadikan matan sebagai metode penanggalan hadis, tetapi juga melalui kitab-kitab hadis. Terkait metode ini, ia mempopulerkannya dengan istilah $e$ -

\footnotetext{
${ }^{27}$ Harald Motzki, Dating Muslim
} Tradistions: A Survey, dalam Arabica, 211. 
silentio yakni apabila sebuah hadis tidak pernah digunakan sebagai argumen hukum ketika membahas suatu permasalahan yang eksistensinya diharapkan, maka hadis tersebut dianggap tidak pernah ada. Atau jika hadis tersebut tidak ditemukan dalam koleksi hadis, maka hadis tersebut tidak ada pada saat koleksi hadis tersebut dibuat. $^{28}$

Argumen tersebut mempunyai empat kelemahan. Pertama, sebuah hadis tidak digunakan mungkin mempunyai beberapa alasan. Adapun alasan ketiadaan hadis merupakan salah satunya. Alasan lain mungkin saja orang tersebut belum mengetahui hadis tersebut. Kedua, dalam sebagian besar kasus, kita tidak mengetahui apakah sumber tersebut mencerminkan perselisihan yang berhubungan dengan hukum atau tidak. ${ }^{29}$ Ketiga, ia tidak mengecek seluruh materi hadis secara sempurna. Keempat, masih banyak hadis yang tertulis dalam manuskrip yang belum ditemukan. ${ }^{30}$

${ }^{28}$ Kamaruddin Amin, Menguji Kembali Keakuratan Metode Kritik Hadis, (Jakarta: Hikmah, 2009), 174.

${ }^{29}$ Harald Motzki, Dating Muslim Tradistions: A Survey, dalam Arabica, 215.

${ }^{30}$ Sahiron Syamsuddin, Pemetaan Penelitian Orientalis Terhadap Hadis, dalam Orientalisme al-Qur'an dan Hadis, 52.
Tokoh lain yang melanjutkan metode ini adalah G.H.A.Juynboll. Ia mencoba menerapkam metode ini dalam tulisannya yang berjudul "The man kadhaba Traditions and the Prohibitions of Lamenting the Death". Motzki berpandangan hadis ini tidak secara jelas mempunyai karakter hukum. Dalam meneliti hadis ini, ia memulainya dengan dua langkah. Pertama, dia meneliti hadis-hadis yang tersusun di Hijaz, Mesir, dan Iraq.

Hasil dari penelitiannya menunjukkan bahwa hadis tersebut tidak terdapat pada koleksi-koleksi yang ada di Hijaz dan Mesir sebelum tahun $180 \mathrm{H}$, merujuk pada Muwatta' Imam Malik yang meninggal tahun 179 H. Akan tetapi, hadis ini ditemukan pada buku Imam Syafi'i (w. 197 H) dan musnadnya al-Humaidy (w. 219 H) yang mana keduanya merupakan ulama Hijaz. Jika demikian, menurut Juynboll, hadis tersebut pasti mulai beredarnya di Hijaz antara karya Imam Malik dengan Imam Syafi'i dan al-Humaidi. Orang yang menciptakan hadis ini adalah orang yang meninggal pada tahun 180 atau $190 \mathrm{H}$. Implikasinya, sanad yang bersambung dari dia sampai nabi dianggap palsu. ${ }^{31}$

\footnotetext{
${ }^{31}$ Harald Motzki, Dating Muslim
} Tradistions: A Survey, dalam Arabica, 215. 
Sementara itu, hasil penelitian di Irak menunjukkan bahwa hadis tersebut tidak ditemukan pada karya sebelum musnad al-Tayalisi (w. 203 H) seperti al-Gami karya Rabi’ bin Habib (w. $\quad 170 \quad$ H). Fakta tersebut menyimpulkan bahwa hadis tersebut pasti beredarnya di Irak pada zaman antara kematian Rabi’ bin Habib dan alTayalisi. Figur utama dalam hadis tersebut adalah Shu'ba bin al-Hajjaj (w. $160 \mathrm{H}$ ), yang tinggal di Basrah dan Kufah, Abu Awana al-Waddah bin 'Abdullah (w. $176 \mathrm{H}$ ) di Wasit dan Basrah, dan 'Abdullah bin Abi Awfa (w. 174 H) yang hidup di Mesir, walaupun mayoritas guru-guru dan murid-muridnya ada di Irak. ${ }^{32}$ Dengan demikian, isnad yang sampai kepada nabi dianggap sebagai palsu.

Akan tetapi, Motzki meragukan argumen yang dibangun oleh Juynboll dengan beberapa alasan. Pertama, ia berpandangan bahwa selama abad ke-2 dan ke-3 Hijriyyah, hadis tidak disusun dengan mengumpulkan manuskrip yang dibuat oleh para pendahulu, melainkan dengan cara mendengar dan merekamnya di kelas. Kedua, pengumpulan hadis pada awal Islam dianggap sebagai satu fenomena dari sekian banyak materi. Ketiga, seorang

${ }^{32}$ Harald Motzki, Dating Muslim Tradistions: A Survey, dalam Arabica, 216. penyusun hadis terkadang merevisi tulisannya setelah dia mendapat riwayat baru. Keempat, banyak dari kitab-kitab hadis tidak disandarkan pada penulisnya langsung, melainkan pada murid-murid yang mengumpulkannya. ${ }^{33}$

\section{Penanggalan Berdasarkan Isnad}

Metode yang ketiga ini sudah lazim digunakan oleh umat Islam dalam kajiannya terhadap hadis. Sanad merupakan serangkaian perawi yang mentransmisikan hadis dari Nabi sampai kepada pengumpul hadis dalam sebuah kitab atau yang disebut mukharrij hadis. Sanad ini biasanya dijadikan tolak ukur dalam menentukan kesahihan suatu hadis berdasarkan rawi. ${ }^{34}$ Berbeda dengan kritik matan yang berkaitan dengan syad dan illat, kritik sanad berusaha mengecek ketersambungan, kedhabitan, dan keadilan seorang perawi. Namun, bagi para orientalis awal seperti Goldziher, sanad tidak dapat dijadikan patokan keotentikan hadis. Pernyataan ini masih diamini oleh orientalis sesudahnya seperti Josep Schacht dan Juynboll.

${ }^{33}$ Sahiron Syamsuddin, Pemetaan Penelitian Orientalis Terhadap Hadis, dalam Orientalisme al-Qur'an dan Hadis, 51.

${ }^{34}$ Umi Sumbullah, Kritik Hadis: Pendekatan Historis dan Metodologis, 28. 


\section{Analisi Josep Schacht terhadap Isnad}

Dalam mengkaji hadis, Schacht lebih banyak menyoroti aspek sanad daripada matan. Terkait dengan hal ini, ia menawarkan lima aturan untuk menetapkan penanggalan melalui isnad. Kelima hal tersebut adalah sebagai berikut: ${ }^{35}$

Pertama, isnad yang paling sempurna dan lengkap adalah yang muncul paling belakang;

Kedua, jika ada isnad hadis yang berhenti pada level akhir misalnya pada level tabi'in, selain isnad yang mencapai otoritas lebih tinggi, maka yang terakhir dianggap sekunder yang disebut Schacht dengan istilah backwards growth of isnad";

Ketiga, varian isnad yang muncul pada sumber yang datang belakangan dengan periwayat tambahan adalah palsu. Ia menyebutnya dengan spread of isnad;

Keempat, keberadaan common link dalam sebagian besar isnad dalam suatu hadis menjadi indikasi kuat tradisi tersebut berasal dari common link tersebut;

Kelima, variasi isnad yang berasal dari common link muncul belakangan.

${ }^{35}$ Harald Motzki, Dating Muslim Tradistions: A Survey, dalam Arabica, 220.
Schacht menganggap isnad sebagai bagian paling kesewenangwenangan dalam hadis. Selain itu, dia juga berpandangan bahwa rangkaian sanad yang terdapat periwayat dari abad ke-2 dan ke-3 Hijriyyah sering diletakkan dengan sembarangan. Isnad yang menggambarkan periwayat berbeda pada level generasi yang sama adalah tidak pasti dan acak atau mana suka. Isnad baginya hanyalah sebuah khayalan belaka yang dibuat oleh ulama untuk melegitimasi pendapatnya agar diakui sebagai toritas yang sampai pada Nabi. Schacht juga mengklaim bahwa periwayatan yang melibatkan keluarga tidak otentik. Namun, menurut Motzki, hal tersebut merupakan sesuatu yang alami, meriwayatkan suatu hadis kepada anggota keluarganya. ${ }^{36}$

Salah satu istilah yang melekat pada Schacht adalah common link. Common link adalah istilah untuk seorang periwayat hadis dari seorang yang berwenang dan lalu ia menyiarkannya kepada sejumlah murid yang pada gilirannya kebanyakan dari mereka menyiarkan lagi kepada dua atau lebih muridnya. Dengan kata lain, common link adalah periwayat tertua yang disebut dalam berkas isnad yang

\footnotetext{
${ }^{36}$ Harald Motzki, Dating Muslim
} Tradistions: A Survey, dalam Arabica, 222. 
meneruskan hadis kepada lebih dari satu murid. ${ }^{37}$

Menurut Schacht, common link adalah persimpangan antara bagian khayalan dan nyata dari sebuah sanad. Bagian khayalannya terdapat pada periwayat yang lebih awal dari common link. Sementara, bagian nyatanya adalah terdiri dari beberapa urutan dari common link ke para pengarang kitabkitab hadis. Common link lah yang membawa hadis ke dalam peredaran yang luas. Ia juga menyatakan bahwa kegunaan common link adalah menatapkan penanggalan terhadap hadis-hadis. ${ }^{38}$

Sebuah riwayat yang memiliki berbagai jalur sanad tidak dapat diterima oleh Schacht. Hal ini menjadi objek baginya untuk mengetahui kapan pertama kali riwayat itu muncul dengan membandingkan sanad-sanadnya. Namun, ia tidak menyuguhkan metode penanggalan riwayat, melainkan hanya memberikan aturan-aturan penanggalan hadis. ${ }^{39}$ Dengan metode perbandingan

\footnotetext{
${ }^{37}$ Ali Masrur, Teori Common Link G.H.A Juynboll: Melacak Akar Kesejarahan Hadits Nabi, (Yogyakarta: Lkis, 2013), 3.

${ }^{38}$ Harald Motzki, Dating Muslim Tradistions: A Survey, dalam Arabica, 222.

${ }^{39}$ Sahiron Syamsuddin, Pemetaan Penelitian Orientalis Terhadap Hadis, dalam Orientalisme al-Qur'an dan Hadis, 52 .
}

jalur sanad ini, ia menemukan common link dalam suatu hadis.

Common link biasanya terletak pada masa tabi'in. Bagi Schacht, ia bertanggung jawab dalam persebaran hadis, sehingga ia dianggap sebagai pencipta hadis. Schacht tidak mempercayai rangkaian sanad dari common link (tabi'in) sampai Nabi, tetapi dia mengakui sanad dari common link sampai ke mukharrij hadis. Dengan demikian, ia menyangsikan keotentikan suatu hadis karena baginya, hadis hanyalah produk dari common link yang tidak pernah sampai sanadnya kepada Nabi.

\section{Metode Juynboll terhadap Analisis Isnad}

Walaupun Schacht orang yang pertama kali memperkenalkan common link, tetapi Juynboll lah orang yang mengembangkannya lebih jauh dan banyak mengaplikasikan metodenya. Juynboll sepakat dengan Schacht terkait penafsiran common link dan bagian isnad yang kembali kepada otoritas yang lebih awal. Menurut Juynboll, common link merupakan pencetus hadis. Lebih jauh dia menyatakan bahwa bagian nyata dari common link hanya muncul dari tingkat tabi'in 
sampai ke penghimpun kitab-kitab hadis. $^{40}$

$$
\text { Perbaikan Juynboll terhadap }
$$
metode common linknya Schacht adalah pada istilah bagian nyata dari isnad, yakni periwayat antara common link ke penyusun kitab hadis. Menurutnya, harus dibedakan antara jalur yang melalui partial common link dan jalur tunggul yang tidak melewati jalur manapun. Yang pertama dapat dianggap bernilai sejarah, sedangkan yang kedua tidak bernilai sejarah selama sumber-sumber lain tidak menunjukkan kembali kepada common link. ${ }^{41}$ Dalam istilah lain, Juynboll membedakan common link menjadi common link utama dan bukan-utama.

Common link yang bukan-utama bertanggung jawab dalam pembuatan hadis. Dengan demikian, penanggalan hadis lebih mundur ke belakang di banding Schacht. ${ }^{42}$ Jika Schacht meyakini common link berada pada masa tabi'in, Juynboll mungkin saja pada masa sebelumnya.

Selain itu, Juynboll juga membahas fenomena isnad yang

${ }^{40}$ Harald Motzki, Dating Muslim Tradistions: A Survey, dalam Arabica, 224.

${ }^{41}$ Harald Motzki, Dating Muslim Tradistions: A Survey, dalam Arabica, 224.

${ }^{42}$ Sahiron Syamsuddin, Pemetaan Penelitian Orientalis Terhadap Hadis, dalam Orientalisme al-Qur'an dan Hadis, 52-53. terkadang melewati common link. Ia menyebut fenomena ini dengan menyelam. Ia menganggaap hal tersebut adalah rekayasa para pengumpul hadis atau para informan pengumpul tersebut. Pandangan ini didasarkan pada dua argumen. Pertama, metode penanggalan didasarkan pada koleksi hadis yang pertama kali muncul. Contohnya seperti Ibnu Hanbal adalah orang yang bertanggung jawab terhadap jalur tunggal karena hadis tersebut hanya ditemukan pada musnadnya. Kedua, berdasarkan analisis isnad- cummatan. $^{43}$

Menurut Motzki, walaupun Juynboll telah memaparkan premispremisnya, bukan berarti tidak meninggalkan pertanyaan. Ada tiga hal yang menjadi catatan Motzki. ${ }^{44}$ Pertama, asumsi bahwa common link adalah pencetus hadis dan jalur tunggal dari common link ke nabi adalah jalan yang dibuat oleh common link, menurut Motzki adalah generalisasi yang bermasalah. Sangat mungkin jika common link menerima hadis dari orang lain dan menamai informannya ketika periwayatan karena hal tersebut

\footnotetext{
${ }^{43}$ Harald Motzki, Dating Muslim Tradistions: A Survey, dalam Arabica, 225. ${ }^{44}$ Harald Motzki, Dating Muslim Tradistions: A Survey, dalam Arabica, 226.
} 
merupakan suatu yang normal dalam transmisi suatu hadis.

Kedua, terkait dengan pembagian antara common link historis dan non-historis. real common link mempunyai nilai historis, sedangkan, jalur tunggul bersifat non-historis. Dalam hal ini terdapat aturan umum yang menyatakan bahwa semakin banyak jalur periwayatan yang datang dari satu periwayat tertentu, semakin banyak pula klaim historisitasnya. Ini sangat masuk akal, tetapi tidak dalam prakteknya. Ketika Juynboll mengilustrasikan diagram analisis isnadnya. Dalam banyak kesempatan partial common linknya muncul pada level periwayat-periwayat tersebut yang secara langsung merujuk pada common link. Kebanyakan jalur periwayatan antara partial common link dengan koleksi-koleksi hadis adalah jalur tunggal. Jika merujuk pada aturan umum Juynboll, maka sebagian besar hadis contoh dalam artikelnya harus dianggap non-historis. ${ }^{45}$

Ketiga, terkait dengan klaim bahwa penyelaman jalur tunggal adalah bentuk pemalsuan yang dilakukan oleh pengarang koleksi hadis dan informannya. Klaim ini didasarkan

\footnotetext{
${ }^{45}$ Harald Motzki, Dating Muslim Tradistions: A Survey, dalam Arabica, 228229.
}

pada argumen e silentio. Klaim tersebut tidak dapat digeneralisasi karena tiga hal. Pertama, materi yang diajarkan oleh guru adalah untuk kepentingan praktis. Kedua, kemungkinan besar, materi yang diajarkan tidak selalu sama, sehingga tidak semua murid dari seorang guru yang sama mempelajari pelajaran yang sama. Ketiga, timbul keraguan apakah semua koleksi-koleksi awal hadis yang disusun oleh ulama dan diriwayatkan oleh muridnya diriwayatkan secara lengkap dan akurat. Tentu saja di dalamnya terdapat proses pengeditan, seleksi, dan pengaturan. ${ }^{46}$

\section{Penanggalan dengan Isnad-cum-} Matan

$$
\text { Metode terakhir yang }
$$
berkembang di kalangan orientalis adalah isnad-cum-matan. Menurut Sahiron, metode ini digagas dan diaplikasikan oleh Harald Motzki. ${ }^{47}$ Namun, menurut Motzki sendiri, metode ini telah dimulai oleh dua sarjana Barat yaitu Hendrik Kramers yang dipublikasikan tahun 1953 dan Joseph van Ess terbit tahun 1975. Akan tetapi, kemunculan keduanya tidak

\section{${ }^{46}$ Harald Motzki, Dating Muslim} Tradistions: A Survey, dalam Arabica, 230.

${ }^{47}$ Sahiron Syamsuddin, Pemetaan Penelitian Orientalis Terhadap Hadis, dalam Orientalisme al-Qur'an dan Hadis, 53. 
direspons dengan positif. ${ }^{48}$ Adapun Motzki adalah orang yang mengembangkannya lebih jauh, sehingga menjadi lebih dikenal oleh kalangan luas.

Metode ini dipilih karena analisis isnad saja tidak cukup, tetapi harus disertai analisis matan. Hal ini dimaksudkan untuk mendapatkan informasi yang lebih akurat terhadap dua elemen hadis yang paling vital sekaligus. Analisis ini menempatkan posisi sanad dan matan dalam kedudukan yang setara, sehingga analisis terhadap keduanya menjadi seimbang. ${ }^{49}$

Metode ini berangkat dari asumsi bahwa terdapat korelasi antara varian isnad dan varian matan hadis. Jika keduanya merupakan bagian dari proses periwayatan yang nyata (real transmission), maka hal tersebut sangat berharga. Para sarjana yang mengadopsi asumsi ini diyakinkan bahwa tidak mungkin korelasi yang seperti ini merupakan hasil dari pemalsuan yang sistemik karena fenomena korelasi melibatkan pihak

${ }^{48}$ Harald Motzki, Dating Muslim Tradistions: A Survey, dalam Arabica, 50.

49 Maizuddin, Book Review: Analisis Isnad Cum Matan: Mengukur Kritik Hadis Muslim dan Barat Kamaruddin Amin, Menguji Kembali Keakuratan Metodologi Kritik Hadis, (Penerbit Hikmah 2009), dalam jurnal Substantia, Vol. 18, No. 2, (2016), 242. yang sangat luas, sehingga sangat kecil kemungkinan semua periwayat bersekongkol melakukan pemalsuan. Faktanya, sering ada perbedaan antara cabang dan jalur isnad, begitu pula perbedaan dalam matan. Hal ini memungkinkan untuk melakukan pengecekan terhadap analisis isnad dengan menggunakan matan. ${ }^{50}$

Jadi, jika Schacht memandang variasi sanad atau matan sebagai suatu yang patut dicurigai, sebaliknya, Motzki melihat fenomena itu sebagai bukti bahwa suatu hadis tidak bukan hasil dari pemalsuan. Variasi tersebut menunjukkan bahwa hadis memang diriwayatkan berdasarkan hafalan yang mungkin terdapat perbedaan dalam struktur kata dalam sanad, tetapi mempunyai inti atau tema yang sama. Justru tidak masuk akal jika keragaman tersebut dipandang sebagai sebuah persekongkolan karena banyaknya pihak yang terlibat.

Adapun langkah-langkah dalam menerapkan metode ini adalah sebagai berikut: $^{51}$

Pertama, menghimpun semua varian hadis yang dapat ditemuka;

\footnotetext{
${ }^{50}$ Harald Motzki, Dating Muslim Tradistions: A Survey, dalam Arabica, 251. ${ }^{51}$ Harald Motzki, Dating Muslim Tradistions: A Survey, dalam Arabica, 251.
} 
Kedua, semua varian isnad digabungkan dalam bentuk diagram untuk disusun berdasarkan proses periwayatan seperti yang tercermin dari jalur periwayatan untuk mendeteksi partial common link dan common link;

Ketiga, melakukan analisis matan untuk mengetahui apakah common link dapat dianggap sebagai kolektor atau penyebar profesional. Caranya dengan mengumpulkan matan yang berasal dari jalur periwayatan yang berbeda untuk melakukan perbandingan sinopsis satu matan dengan yang lainnya;

Keempat, kelompok varian matan dan isnad dibandingkan untuk mengecek apakah terdapat korelasi atau tidak;

Kelima, jika ada korelasi, maka kesimpulan yang dapat ditarik berdasarkan matan asli yang diriwayatkan oleh common link dan orang yang bertanggung jawab terhadap perubahan matan dapat dilihat melalui jalur periwayatannya setelah common link.

Adapun jika dijelaskan dalam sebuah tabel, penelitian orientalis terhadap hadis berdasarkan metode yang digunakan adalah sebagai berikut:

\begin{tabular}{|c|l|l|}
\hline & $\begin{array}{r}\text { Metode } \\
\text { Penelitian } \\
\text { Hadis oleh } \\
\text { Orientalis }\end{array}$ & $\begin{array}{c}\text { Tokoh- } \\
\text { tokohnya }\end{array}$ \\
\hline 1. & Matan & $\begin{array}{l}\text { Ignaz } \\
\text { Goldziher } \\
\text { Josep } \\
\text { Schacht } \\
\text { Marston } \\
\text { Speight }\end{array}$ \\
\hline 2. & $\begin{array}{l}\text { Kitab-Kitab } \\
\text { Hadis }\end{array}$ & $\begin{array}{l}\text { Josep } \\
\text { Schacht }\end{array}$ \\
\hline 3. & Isnad & $\begin{array}{l}\text { Josep } \\
\text { Schacht } \\
\text { Juynboll }\end{array}$ \\
\hline 4. & $\begin{array}{l}\text { Isnad-cum- } \\
\text { matan }\end{array}$ & $\begin{array}{l}\text { Harald } \\
\text { Motzki }\end{array}$ \\
\hline
\end{tabular}

\section{Kesimpulan}

Sarjana Barat yang pertama mengkaji hadis adalah Ignaz Gholdziher yang kemudian diikuti oleh generasi selanjutnya seperti Josep Schacht dan Juynboll. Berdasarkan metode yang digunakan, ada empat metode penanggalan hadis. Pertama, metode yang menggunakan matan. Tokohnya adalah Ignaz Goldziher, Josep Schacht, dan Marston Speight. Kedua, penanggalan berdasarkan koleksi kitab hadis dengan tokohnya Josep Schacht. Ketiga, penanggalan berdasarkan isnad. Metode ini masih 
diwakili oleh Schacht dan Juynboll. Keempat, metode yang menggunakan matan dan isnad yang dipopulerkan oleh Harald Motzki. Dari keempat metode penanggalan hadis, metode penanggalan menggunakan isnad dan matan merupakan metode yang cukup unggul untuk mengungkap sejauh mana keotentikan suatu hadis.

\section{Daftar Pustaka}

Abbas,Hasyim .Kritik Matan Hadis Versus Muhaddisin dan Fuqaha. Yogyakarta: Kalimedia. 2016.

Amin, Kamaruddin, Menguji Kembali Keakuratan Metode Kritik Hadis, Jakarta: Hikmah. 2009.

Darmalaksana, Wahyudin, Hadis di Mata Orientalis: Telaah atas Pandangan Ignaz Goldziher dan Joseph Schacht, Bandung: Benang Merah. 2004.

Faroh, Mar'ah Nailul, Hadis dan Orientalis (Teori Ignaz Gholdziher dan Joseph Schacht).

Goldziher, Ignaz, Introduction to Islamic Theology and Law, terj. Andras dan Ruth Hamori Princeton: Princeton University Press. 1981.

Idri, Perspektif Orientalis tentang Hadis Nabi: Telaah Kritis dan Implikasinya terhadap Eksistensi dan Kehujjahannya, dalam Al-Tahrir, Vo. 11, No. 1. 2011.

Maizuddin, Book Review: Analisis Isnad Cum Matan: Mengukur Kritik Hadis Muslim dan Barat Kamaruddin Amin, Menguji Kembali Keakuratan Metodologi Kritik Hadis, Penerbit Hikmah: 2009, dalam jurnal Substantia, Vol.18, No. 2. 2016. 
Masrur, Ali, Teori Common Link G.H.A Juynboll: Melacak Akar Kesejarahan Hadits Nabi, Yogyakarta: Lkis. 2013.

Masrur, Ali, Skeptisisme Ignaz Goldziher (1850-1921) terhadap Autentisitas Hadits dan Berbagai Tanggapannya, dalam jurnal Wawasan, Vol. 34, No. 2. 2011.

Motzki, Harald, Dating Muslim Tradistions: A Survey, dalam Arabica, Leiden: Koninklijke Brill, 205, Vol. 52.

Sumbullah, Umi, Kritik Hadis: Pendekatan Historis dan Metodologis, Malang: UIN Malang Press. 2008.

Syamsuddin, Sahiron, Pemetaan Penelitian Orientalis Terhadap Hadis”, dalam Orientalisme al-Qur'an dan Hadis, ed. Nur Kholis setiawan \& Sahiron Syamsuddin, Yogyakarta: Nawesea Press. 2007.

Zuhri, Muh, Perkembangan Kajian Hadis Kesarjanaan Barat, dalam Ulul Albab Vol. 16, No. 2. 2015. 